\title{
Probiotic Spore Formers Enhances Host Health
}

\author{
Anu P Sebastian ${ }^{1}$ and Keerthi TR ${ }^{2 *}$ \\ ${ }^{1}$ Department of zoology, Assumption college Autonomous, India \\ ${ }^{2}$ Mahatma Gandhi University, India
}

Submission: July 20, 2018; Published: August 14, 2018

*Corresponding author: Keerthi TR, Professor \& Director, School of Biosciences, Mahatma Gandhi University, Kottayam- 686560, India; Tel: 919497655293; Email: keerthisureshbabu@gmail.com

\begin{abstract}
Wild species of spore formers from various sources has remarkable probiotic potential. Many of the isolates possess non-hemolysis, nonlecithin's activity, acid and bile tolerance, resistance to artificial gastric and intestinal fluids and antagonistic action towards pathogens. Most of the spores and vegetative cells of isolates showed excellent resistance to acid and bile. Many of the wild species of sporeformers are able to produce siderophores, and antimicrobial substances. Adhesive rate of sporeformers were found to be more than vegetative cells on intestinal mucous. Both spores and vegetative cells were auto aggregating but auto aggregation of vegetative cells was found to be more than that of spores. Vegetative cells of isolates coaggregated pathogens while spores remained to be nonaggregating. In vivo Immunomodulatory studies also proved that the sporeformers has a significant role in improving both humoral and cell mediated immunity. Ingestion of probiotic spores is very significant because they can survive in the harsh gastrointestinal conditions which further form vegetative cells during favorable situations.

Keywords: Probiotic; Sporeformers; Antagonism; Cell surface property; Gut immunity
\end{abstract}

\section{Introduction}

The concept of probiotics has a long history of health claims. For example, in a Persian version of the Old Testament (Genesis 18:8), it states "Abraham owed his longevity to the consumption of sour milk. Replacing in-feed antibiotics with non-antibiotic alternatives is, therefore, an ever-increasing necessity. However, the withdrawal of all growth promoting factors is not a simple matter since this will not only affect feed efficiency but will also increase the mortality and morbidity of animals [1]. Sporeformers are capable of growth and metabolic activity only when in the vegetative state, and resort to sporulation when conditions of inadequate nutrition or other challenge to survival is experienced [2]. Currently, there is no universalclass of probiotic bacterium although the most common types available are lactic acid bacteria (e.g., Lactobacillus spp.). These bacteria are found normally in the gastrointestinal tract (GIT) of humans and animals and there is the vague notion that the use of indigenous or commensal microorganisms is somehow restoring the natural microflora to the gut. A second class comprises those that are not normally found in the GIT. For example, Saccharomyces boulardii has been shown to be effective in preventing the recurrence of Clostridium difficile-induced pseudo membranous colitis [3] as well as the antagonistic action of Escherichia coli [4]. S. boulardii products are currently being marketed for human use. Within this group of allochthonous probiotic microbes are the sporeforming bacteria, normally members of the genus Bacillus. Here, the product is used in the spore form and thus can be stored indefinitely on the shelf. The use of spore-based products raises a number of questions though. Since the bacterial species being used are not considered resident members of the gastrointestinal microflora how do they exert a beneficial effect? Because the natural life cycle of Initial efforts to document a physiological impact of probiotic bacteria often focus on the following three criteria:

a) inherent characteristics of strains that would enable intestinal tract survival

b) the fate of the fed bacterium, and

c) the impact of consumption of the live bacterium on intestinal flora.

It should be noted, however, that effects beyond an impact on intestinal flora, and at extra intestinal sites, have been documented for many probiotic strains [4]. A few such studies have been done with sporeformers. Hydrophobicity, auto aggregation and mucin adhesion are important attributes which help in the attachment to various substrata that explain the probiotic nature of the microorganism [5].

\section{The Gut as A Habitat for Sporeformers}

Since spores of Bacillus species can readily be found in the soil, one might assume that the live (vegetative) bacteria that produced these spores are also soil inhabitants. This, however, is proving an unfounded assumption and, of course, the ability of spores to be dispersed in dust and water means that spores 
can be found almost everywhere. So, where they are found does not indicate their natural habitat. Bacillus spore-forming species are commonly found in the gut of animals and insects and experimentally this is often demonstrated by faecal sampling [6]. The presence of Bacillus species, whether as spores or vegetative cells, within the gut could arise from ingestion of bacteria associated with soil endosymbiotic relationship with their host, being able temporarily to survive and proliferate within the gastrointestinal tract (GIT). In some cases, though, the endosymbiont has evolved further into a pathogen, exploiting the gut as its primary portal of entry to the host (B. anthracis) oras the site for synthesis of enterotoxins (B. cereus, B. thuringiensis) [7].

\section{Antagonistic Mechanism of Sporeformers}

There are different mechanisms by which probiotic can exert inhibition towards pathogens. Production of bacteriocin and cell surface properties are the two major way to eliminate pathogens. Enteric pathogens are of great importance because they cause infections both in man and animals. A comparative study of two sporeformers Bacillus coagulans and Bacillus clausii found to produce inhibitory substances against Salmonella typhi, Bacillus subtilis and Klebsiella. [6]. find out the inhibitory effect of Bacillus sporeformers against enteric fever pathogen [8]. Comparative studies on the adhesion and cell surface properties of sporeformers and enteric pathogens are scarce in the field of probiotic research. Hydrophobicity, auto aggregation and mucin adhesion are important attributes which help in the attachment to various substrata that explain the probiotic nature of the microorganism [5]. Sporeforming isolates, possessed basic probiotic qualities and cell surface properties which enable them to fight against enteric pathogens [8]. found that through adhesion ability and colonization on [9] tissues, probiotic microorganisms can prevent pathogen access by steric interactions or specific blockage on cell receptors. An experimental study of [10] reveals that both spore and vegetative phases of isolates possess a different rate of adhesion potentials, which indicates that cell surface properties were involved in adhesion process. Compared to spores, vegetative cells of selected isolates remains to be less adhesive on intestinal mucous. This study also reveals that increased adhesion of the spore phase of the isolates, on intestinal mucin than their corresponding vegetative cells may be due to their hydrophobic nature. Spores adhered better than the corresponding vegetative cells on mucin. Adherence of organisms to xylene, a non-polar solvent, demonstrates hydrophobic nature of the isolates. Increased hydrophobic nature of spores than their corresponding vegetative cells may be due to presence of hydrophobic proteins present in spore coat and found that cell surface properties of bacteria, especially sporeformers play key role in adhesion mechanism. Hydrophobic cell surface nature of Bacillus coagulans and Bacillus clausii also reported by [6]. Doyle RJ [11] found that agents which disrupt protein structure modified the hydrophobicity of spores, suggesting that the spore coat also has hydrophobic sites. In vivo colonization, of MBTU PBBM1 Bacillus subtilis spores establish the adhesion ability and there by exert probiotic effects in gastrointestinal tract (GIT). A stable colonization in gastrointestinal tract was noticed in animals which received 108 spores of MBTU PBBM1 and this indicates that a particular dose is necessary for the establishment of administered spores in the gastrointestinal tract of mouse [12].

\section{Immune Stimulation of Probiotic Sporeformers}

A number of studies in humans and animal models have provided strong evidence that oral administration of spores stimulates the immune system. This tells us that spores are neither innocuous gut passengers nor treated as a food. A small proportion of spores have been shown to disseminate to the primary lymphoid tissues of the GALT (Peye_s Patches and mesenteric lymph nodes) following oral inoculation [13] and in vitro studies have shown that phagocytosed spores can germinate and express vegetative genes but are unable to replicate [14]. Following oral dosing, anti-spore IgG responses could be detected at significant levels. Anti-spore IgG and secretory IgA (sIgA) could be produced by a normal process of antigen uptake by B cells. Detailed analysis of the subclasses showed IgG2a to be the initial subclass produced and this is often seen as being indicative of a type 1 (Th1) T-cell response [15]. Th1 responses are important for IgG synthesis but more importantly for CTL (cytotoxic $\mathrm{T}$ lymphocyte) recruitment and are important for the destruction of intracellular microorganisms (e.g., viruses, Salmonella spp.) and involve presentation of antigens on the surface of the host cell by a class I MHC processing pathway. Support for Th1 responses has been provided by the analysis of cytokines in vivo that showed synthesis of IFN- and TNF in the GALT and secondary lymphoid organs when spores of B. subtilis or B. pumilus were administered to mice [14]. Serum Ig A and Serum Ig G antibodies are implicated in host defense against bacterial infections. Study conducted by [10] resulted MBTU PBBM1 spores have capacity to stimulation of serum Ig A and serum Ig G in treated groups in a dose dependent manner. This means that spores can modulate humoral immune response.

\section{Immunomodulation of Sporeforming Probiotics}

Stimulation of the immune system, or immunomodulation, is considered an important mechanism to support probiosis. A few studies in humans and animal models have provided strong evidence that oral administration of spores stimulates the immune system. Large number of probiotic products in use today are bacterial spore formers, mostly of the genus Bacillus [16]. Stimulation of the immune system, or immunomodulation, is considered an important mechanism to support probiosis. A number of studies in humans and animal models have provided strong evidence that oral administration of Bacillus spores stimulates the immune system. Dose dependent studies [10] revealed that group which receiving $1 \times 108$ spores showed an effective humoral and cell mediated immune response in balb/c 
mice. So this dose can be decided as an appreciable measure which can evoke a effective humoral and cell mediated immune response. Studies also revealed that this strain could colonize gastrointestinal tract which would further act as a key to the initiation of immunomodulation. 30 days consumption of MBTU PBBM1 spores had no adverse effects on animals' general health status, hematology, gut mucosal histology parameters. The bacterial translocation was not observed $[17,18]$. Results suggests that the ingestion of MBTU PBBM1 would enhance the immunity indicating immunomodulatory effect.

\section{References}

1. Huyghebuert G (2003) Replacement of antibiotic in poultry. Eastern nutritional conference 18-19 May, Canada, pp. 55-78.

2. Sanders ME, Morelli L, Tompkins T (2003) A Spore formers as human probiotics: Bacillus, Sporolacto bacillus, and Brevi bacillus . Comprehensive Rev Food Sci Food Safety 2: 101-111.

3. Czerucka D, Rampal P (2002) Experimental effects of Saccharomyces boulardii on diarrheal pathogens. Microbes Infect 4: 733-739.

4. Reid G, Sanders ME, Gaskins HR, Gibson G, Mercenier A, et al. (2003) New scientific paradigms for probiotics and prebiotics. J Clin Gastroenterol 37(2): 105-118.

5. Anil KP, Ahire JJ, Pawar SP, Chaudhari BL, Shouche YS, et al. (2010) Evaluation of Probiotic Characteristics of Siderophore genic Bacillus spp. Isolated from Dairy Waste. Applied Biochemistry and Biotechnology 164: 386-400.

6. Honey Chandran C, Summaya Jauhara, Keerthi TR (2016) Probiotic effect of Bacillus coagulans, mbtu-p1f2 from in fant faeces with a known probiotic European journal of biomedical and pharmaceutical sciences 3(3): 298-304.

7. Jensen GB, Hansen BM, Eilenberg J, Mahillon J (2003) The hidden lifestyles of Bacillus cereus and relatives. Environ Microbiol 5(8): 631640.
8. Anu P Sebastian, Keerthi TR (2012) Probiotic effect of wild species of Bacillus spore formers and its effect on enteric pathogens. International Journal of Pharma and Bio Sciences3(1): 327-334.

9. Otero MC, Ocana VS, Macias E (2004) Bacterial surface characteristics applied to selection of probiotic microorganisms. Methods Mol Biol 268: 435-440.

10. Anu P Sebastian, Keerthi TR (2012) Adhesion and cells surface properties of wild species of spore formers against enteric pathogens in Asian Pacific Journal of Tropical Medicine 6(2): 110-114.

11. Doyle RJ, Nedijathaiem F, Singh JS (2000) Hydrophobic characteristics of Bacillus spores. Current Microbiology10(6): 329-332.

12. Anu P Sebastian, Keerthi TR (2014) Immunomodulatory effect of probiotic strain Bacillus subtilis MBTU PBBMI spores in Balb/C Mice. International Journal of Engineering and Technical Research 2(11).

13. Duc LH, Hong HA, Fairweather N, Ricca E, Cutting SM (2003) Bacterial spores as vaccine vehicles. In fect Immunol 71(5): 2810-2818.

14. Duc LH, Hong HA, Barbosa TM, Henriques AO, Cutting SM (2004) Characterisation of Bacillus probiotics available for human use. Applied and Environmental Microbiology 68(5): 2344-2352.

15. Robinson K, Chamberlain LM, Schofield KM, Wells JM, Le Page RWF (1997) Oral vaccination of mice against tetanus with recombinant Lactococcuslactis . Nat Biotechnol 15(7): 653-657.

16. Hong HA, Le Hong Duc, Simon M, Cutting (2004) The use of bacterial spore formers as probiotics. FEMS Microbiology Reviews 29(4): 813835.

17. Nicholson WL (2002) Roles of Bacillus endospores in the environment. Cell Mol Life Sci 59(3): 410-416.

18. Czerucka D, Dahan S, Mograbi B, Rossi B, Rampal P (2000) Saccharomyces boulardii preserves the barrier function and modulates the signal transduction pathway induced in enteropathogenic Escherichia coliinfected T84 cells. In fect Immunol 68: 5998-6004.

\section{Your next submission with Juniper Publishers} will reach you the below assets

- Quality Editorial service

- Swift Peer Review

- Reprints availability

- E-prints Service

- Manuscript Podcast for convenient understanding

- Global attainment for your research

- Manuscript accessibility in different formats ( Pdf, E-pub, Full Text, Audio)

- Unceasing customer service

Track the below URL for one-step submission https://juniperpublishers.com/online-submission.php 